\title{
RELIGIOUS EDUCATION AND EXTREMISM IN PAKISTAN: FROM DEOBANDI MILITANCY TO A RISING SUFI FANATICISM
}

\author{
SYED SUBTAIN HUSSAIN SHAH \\ Faculty of Political Science and International Studies, \\ University of Warsaw, 26/28 Krakowskie Przedmieście St. \\ WNPISM Auditorium Building \\ 00-927 Warsaw, Poland \\ Email address: sibshah@yahoo.com
}

\begin{abstract}
Aim. The aim of this research article is to verify waves of fanaticism among the followers of the Barelvi sect, a branch of Sufi Islam along with continuation of violent extremist activities by the followers of the Deobandi brand of the Muslim religion in Pakistan. It has been evidenced that Pakistan's society has been badly influenced by religious extremism since the 1980s (Gul, 2012). Fitzgerald (2011) termed the religion as a force of nature which is absolutely appropriate for the case of religious extremism in Pakistan. The religious extremism in Pakistan can be examined through the concept of social constructivism which emphasizes characterisation of human identity, values and norms in the society (Sajjad, 2015).

Method. The qualitative method of research was employed to analyse circumstances related to growing Sufi's fanaticism in Pakistan. The data was collected from different sources including books, scientific journals, research articles, newspapers and websites.

Results. By using various valuable references, it has been verified that support of the state in the 1980s caused growth of Deobandi extremism, as well as support by the state in order to counter some of the Deobandi fanatic groups in the 1990s and 2000s led to occurrence of Barelvi fanaticism in the country.

Conclusion. The study confirms that Pakistan, which was already witness of Deobandi militancy, is facing the more challenging fanaticism of Barelvis, having strong tendencies toward radicalization and extremism on the religious issues like blasphemy.

Key words: religious education and extremism, Pakistan, Deobandi militancy, Sufi fanaticism.
\end{abstract}

\section{INTRODUCTION}

Pakistan's society has been badly influenced by religious extremism since the 1980s especially after the initiation of the Afghan Jihad (Gul, 2012). The underlying cause of religious extremism in the country is the employment of religion for strategic, political and vested interests by various patrons e.g. the 
state and different non-state political and religious actors. The more worrying point is that when one religious extremist group turns into a threat to another group or many others. It happens sometimes that, when the state counters or tries to counter the first faction with the assistance of a second group, then the second one occupies the space vacated by the first one. Such a situation usually creates challenges to the moderate and normative ethics of the state and society. In this way the cycle of religious extremism and counter extremism has continued in Pakistan for more than 35 years. Generally, the state projects new religious factions for its social, political and strategic purposes and after achieving the required results, it does not bother to take any interest in fostering its client groups and leaves them without a winding up strategy. In the 1980s, the Zia regime patronized Deobandis ${ }^{1}$ but the Musharraf regime supported Barelvis ${ }^{2}$ in order to counter Deobandi extremism (Said, \& Ahmad, 2016). Deobandi was a religious revivalist movement within Sunni Islam in India in late 19th century and it also spread into Pakistan after partition of the subcontinent in 1947. The name of the movement derives from town of Deoband in India where the first religious seminary of this sect "Darul Uloom Deoband" was founded in 1867 (Ingram, 2009), while the Barelvi sect is named after the town of Bareilly in India, from where this movement was initiated. This was the hometown of the movement's leader Ahmad Raza Khan (Lewis, 2010).

In Pakistan in the post Zia era, it was not only Musharraf's government but also civilian governments before him that took some steps to counter extremism. Specifically, these steps were taken to counter Deobandi extremist groups active in Pakistan, at end of the Afghan war or Afghan jihad, as well as after the collapse of Taliban rule in Afghanistan. These measures included the politicizing of the Sufi brand of Islam (Barelvi sect) in order to handle the Deobandi extremism in the country during various periods specially in the post 9/11 era. The state's investment on Barelvis later on caused some of them also to indulge in extremist activities in the country. Particularly, the emerging tendency of Barelvi extremism especially on the issue of the blasphemy law has shaken the society in Pakistan and resulted in many terrible incidents across the country. Once again, it was madrassa which played a significant role in mobilizing the agitation call by the religious figures belonging to the Barelvi school of thought. The Deobandi madrassa's scholars and students had motivated and produced forces for Zia Islamization, and Afghan Jihad in the past. The Barelvis mobilized the masses for anti-government agitation on the issue of blasphemy in Pakistan most recently. A forceful sit-in at an entry point of Islamabad, the capital city by the supporters of a Barelvi-Sufi group on the issue of blasphemy in November 2017 is seen as a momentous example of the violent act, which caused severe human and other losses and forced the government to accept demands of the protesters.

1 Deobandi is a revivalist movement within Sunni (primarily Hanafi) Islam in South Asia.

2 Barelvi is a faction of Sufi Islam in the Subcontinent of India and Pakistan. 


\section{THEORETICAL AND CONCEPTUAL FRAMEWORK}

Conceptual understanding is essential in a systematic study of an issue. As for religious extremism, it is a complex problem containing religious and political conflicts and these conflicts dominate in various ways such as political or religious pressure, violence and vocal conflicts in the society. Religious extremism means a negative attitude of a particular religious school of thought with other segments of the society. As for Islamic religious extremism, some scholars also named it as a "Muslim extremism," as a shorthand for the violent actions of intolerance committed by Muslims as individuals or groups. The term "Muslim extremism" mostly refers to violent organizations like al-Qaeda or Islamic State (ISIL) (Schubel, 2017).

As for religious school or madrassa, it plays significant role in the religious societies like Pakistan. The term Madrassa means a system of Islamic religious education. The Oxford dictionary describes "Madrassa" as Arabic, "school, college", from "darasa" "to study" (Simpson, \& Edmund, 1989). Another dictionary defines it a school or college, especially a school attached to a mosque where young men study theology (Dictionary, n.d).

Scholars of international relations argue that the relation between religion and politics are linguistically constructing a powerful modern narrative. The scholars say that religion is fundamentally violent and irrational unless controlled by the state. Timothy Fitzgerald discusses how the "religion" appears as a force of nature which either assists or threatens the state (Fitzgerald, 2011). This concept of the religious extremism was absolutely appropriate for the case of religious extremism in Pakistan where religious groups become a natural force in support of the state and where, sometimes, this force poses threats to the state. On the other hand, the social constructivist approach of international relations supposes that human behaviour is defined by their character or identity which is shaped through values and norms of the society and its history. The religious extremism in Pakistan especially creates tussles between the state and the extremist groups that can be examined through the concept of social constructivism (Sajjad, 2015).

\section{OBJECTIVES OF RESEARCH}

- To evaluate impact of religious extremism especially growing Barelvi extremism in the society of Pakistan.

- To explore relevant factors and their linkages to religious extremism including existence of Deobandi militancy and growing Barelvi fanaticism in Pakistan.

- To highlight and evaluate extremism related national security threats to Pakistan along with their implications.

- To recommend viable measures through accurate findings on the subject of religious extremism. 


\section{SIGNIFICANCE OF THE STUDY}

This study examines consequences related to religious extremism in Pakistan and prospect of viable measures for countering the menace. Education played important role in the nation's building as it fills the gap between information and knowledge. It removes deficit of information among the different segments of a nation state (Zaidi, 2012).

Religious extremism is one of the hot issues in Pakistan as it has damaged the image of the country both at the national and international levels. The schools of religious education (Madrassas) also played an important role in spreading extremism in the country. The study assesses different aspects of Pakistan's social system in order to find out the reasons for the disorder and highlights the main contributing factors in this context. Significance of this study further increases as further research work on this topic is required. This study evaluates lack of policy measures and state mechanisms with a view to recommend workable counter actions. Pakistan needs sincere efforts, especially government response to religious extremism which is a main driving source behind terrorism including sectarian violence and it also needs to properly deal with other problems including exploding population growth, ethnic division and other complications in the society. As the majority of the Muslims in Pakistan belong to Barelvi sect of Islam, the emerging fanaticism on issue of blasphemy among the supporters of this sect creates more threats to the security of Pakistan. Their slogan "The blasphemers should be killed" shows the tough and exceptional narrative of this religious group.

\section{HYPOTHESIS}

Religious extremism is one of the most serious challenges for Pakistan because the extremism leads to violent radicalism in the society. Islamization of society, patronage of the favorite religious groups by the state for covert political objectives and irregular religious schools curriculum play a very important role in spreading religious extremism in the country. Support of the state in the 1980s caused growth of Deobandi extremism, as well as support of the state in order to counter Deobandi fanatic groups in the 1990s and 2000s led to occurrence of Barelvi extremism in the country.

\section{IMPORTANT RESEARCH QUESTIONS}

- How and which reasons and factors led to religious extremism in Pakistan?

- How Islamization of the country and Afghan Jihad also contributed to the extremism in the country?

- How religious schools contributed to extremism and violence in the society? 
- What were objectives of the state to patronise Deobandi and Barelvi religious groups in the different eras?

- How and why governments have failed to resolve the conflict?

\section{LITERATURE REVIEW}

Although many writers, experts and analysts have analyzed the issue of extremism in Pakistan according their own knowledge and experience so far, there is less focus on the emerging extremism and fanaticism by the Barelvis in the country. The Sufi brand of Islam was mostly considered a peaceful version of the religion but recent waves of the intense extremism on the issue of blasphemy throughout the country proved that this sect could not remain behind the others. Most of the books and research articles concentrated on role of Zia's Islamization, religious schools and the Afghan Jihad in growth of the religious extremism in the country. An article "The challenge of Religious Militancy and Extremism in Pakistan" emphasized that the Afghanistan conflict has deeply impacted the Pakistanis polity and society. A combination of religious motivation, madrassas, education, Afghan related and later Kashmir related rhetoric, and official patronage instigated and promoted a momentum to religious militancy (Riaz, 2011, p. 209). Though, the book titled: Pakistan Fights Extremism and Terrorism highlighted the problems of extremism saying the issues which caused extremism in masses were neither properly understood or no serious effort was made by the state to address the issue. The author similarly emphasized that Zia's regime, and Afghan war played a crucial role in spreading extremism in Pakistan as these two elements left grave social, economic , political and religious impact on Pakistan (Javaid, 2013, p. 185). Some of the writers pointed out silence of Pakistan's military, the most powerful entity of the state over the growth of extremism in the country. "There is also indication that Pakistan's Army dare not confront the jihadi militants due to certain reasons including a large sympathy of the groups in the country and secondly, the army focused on other issues like fighting in Kashmir (Abbas, 2005, p. 240). A producer of a huge volume of literature on issue of extremism in Pakistan, Amir Rana, in his book The Militant, transliterated that some Shia and Barelvi violent sectarian groups also operate in Pakistan but they are reactionary groups and do not have extensive connectivity with global and regional terrorist groups (Rana, 2015 , p. 94). This argument could be valid but the writer did not captivate emerging Barelvi extremism. A research article titled, "Institutionalization of Sufi Islam After 9/11 and Rise of Barelvi Extremism in Pakistan" emphasized that the society was already divided because of religious extremism before $9 / 11$ and promotion of Barelvi Islam against established extremism further deepened the gulf among the different segments in the country (Said, \& Ahmad, 2016). Examination of most of the literature shows that there are so many missing links in the studies conducted so far on the subject. Much more can be added in order to counter extremism in Pakistan specially keeping in view emerging radicalism among the followers of the Barelvi-Sufi school of thought. 


\section{RELIGIOUS EDUCATION AND EXTREMISM IN PAKISTAN}

Growth of religious extremism was very smooth in the society of Pakistan where the state's organizations, especially its national security institutions such as the military and the intelligence agencies, were engaged in building Pakistani national identity on the basis of religion since the independence of August 1947. This political commitment to an ideological state gradually evolved into a strategic pledge to jihadi ideology (Haqqani, 2005, p. 13). The religious educational system, which was exploited as a useful tool for jihad, played a key role in advancement of extremism as a main motivating force behind the terrorism in Pakistan. The institution for the religious education 'Madrassa' or the Islamic Seminary mostly teaches the religious subjects such as Islamic laws, Arabic language, interpretation and translation of the Islamic holy book "Quran" and Sayings of Prophet of Islam. Though the madrassas belong to all major sects of Islam including Sunnis and Shias, in Pakistan most of the madrassas belong to the Sunni sect as it is Sunni majority state. Among the Sunnis, there are three sub-sects: Deobandis, Barelvis and the Ahl-i-Hadith (salafi). Besides these, the revivalist Jamat-e-Islami also has its own madrassas. All of the Islamic madrassas through their separate central boards on sectarian bases (Rahman, 2016). The number of Madrassas in Pakistan were increased dramatically during and after the reign of former dictator General Zia ul Haque who ruled eleven years over the country in the 1970s and 1980s. Poverty was also one of the reasons why many of the lowest class people preferred to send their children to the madrassa instead the regular school, which resulted in the changing of the intellectual approach of a large number of the masses. The religious schools, which provide food and shelter to the students, commonly attracted the poorest families of Pakistan. But this swift evolution of the religious schooling caused a decline in general standards of scholarship in the society (Murphy, 2013).

The religious clerics belonging to Deobandi sect exploited the opportunity and increased their madrassas in the county. Though the majority of the population in Pakistan are Sufi-Sunni Muslims, most of the madrassas in Pakistan follow the creed of Deobandi sect, the stricter branch of Sunni Islam (Butt, 2006). They educate their students the basics and ideologies of their sectarian version of Islam throughout Pakistan. The moderate Muslim Scholars emphasize tolerance, peace and harmony in the society but many of the madrassas have been identified as a source of religious extremism as well as terrorism, especially providers of suicide bombers in the country. Seeds of extremism in Pakistan were cultivated through a Jihad (a holy war in Islamic concept) against Soviet Forces in Afghanistan and a number of religious schools in different areas of Pakistan produced a human force for this so-called Islamic war in the neighboring country. Especially the Deobandi School of Islamic thought was premeditated by the state during Afghan Jihad in the 1980s. A Pakistani intellectual who later on became Pakistan's Ambassador to United States defined that situation as exploring, "Pakistan, long wanted to extend its influence into Afghanistan, willingly accepted U.S. help and became the 
staging a ground for the guerrilla war against the Soviet Union in Afghanistan" (Haqqani, 2005).

It is known to everyone that Pakistan was a base camp for the foreign sponsored Afghan Jihad and number of the madrassas of the specific school of Islam rapidly increased in Pakistan. It was the Afghan war, in which not only madrassa played its role but also students of colleges and universities were not disjointed from the situation. The writer Muhammad Amir Rana revealed, "A large number of the students from colleges and universities joined jihad through Jamaat e Islami (JI) Pakistan and its subsidiary groups" (Rana, 2015). Afterwards, the extremists redundant from the Afghan Jihad tried to find a space in the Pakistani society which caused further rise of extremism in the following phases, including post-cold war and post 9/11 eras in the country. As a consequence in last three and half decades since the Afghan jihad, Pakistan has been severely facing extremism and terrorism committed by the radical groups associated with Deobandi School of law. Despite of measures conducted by the state, these groups still steer most of the terrorist activities across the country.

Particularly after the Afghan jihad and fall of Taliban's regime in Afghanistan, some of the Deobandi extremist groups widely enlarged their violent activities in Pakistan. The Government of Pakistan took some important measures to counter such activities, especially after 9/11, and politicizing Sufi brand of Islam was one of the steps taken by the state in order to counter Deobandi extremism in the country. Mainly the regime under former military ruler General Musharraf initiated to empowerment of Barelvis in Pakistan (Suleman, 2017a). The enablement of Barelvi groups later caused some of them to start extremist activities in the country. The emerging tendency of Barelvi extremism principally on the issue of the blasphemy law has shaken the society in Pakistan. Again, the religious schools played an important role as thousands of students of Barelvi's madrassas came out to the streets for agitation on the controversial blasphemy law of the country. The speeches by religious leaders of Barelvi's sect on the issue resulted into many terrible incidents across the country in the post 2010 era. There were sequences of episodes including assassination of Salman Tasir, the Governor of Punjab, the most populated province of Pakistan in January 2011 and most recently a violent sit-in of followers of a Barelvi group in Islamabad, the capital city in November 2017, which caused loss of human lives and damage to property. Not only Islamabad, but other major cities of Pakistan were also severely affected by the violent agitation of Barelvi's supporters.

\section{ZIA'S ERA AND ITS IMPACT ON PAKISTANI SOCIETY}

The military dictator General Zia ul Haque (1977-1988) came to power by toppling the elected government of then Prime Minister Zulfiqar Ali Bhutto in 1977. He not only dismissed the Prime Minister but also suspended the constitution of the country and held up the electoral and democratic process for a long time. It was the period when two important developments occurred in the 
Pakistani neighbourhood. The first one was Islamic Revolution in Iran which threatened Arab states of the region and the second one was the Soviet invasion of Afghanistan, which was a challenging episode for Pakistan.

The U.S. and Arab states joined to contain Iran and as well as U.S., Arabs and Pakistan cooperatively started to help the Afghans for waging a jihad (holy war) against the communist occupation forces in Afghanistan. Pakistan's military regime performed a crucial role in this jihad. General Zia not only provided a realistic ground for the so-called holy war but also tried to make an important pretext for continuation of his autocracy through Islamization at home. Religious education played a very important role in the both cases: Afghan Jihad as well as Islamization of the country. So, Zia endeavoured to execute his authority to intensely adjust the Madrassa's system in Pakistan. Therefore, the religious education and elements in Pakistan became important tools for the process of Islamization and fighting against Soviet Union in Afghanistan. These trends cultivated a communally hostile environment and varieties of fundamentalisms in Pakistan. The religious militancy in the society was fortified which caused eruption of a violent sectarian division as well as extremism in the society.

Zia's regime introduced Islamic rules for every institution and individual in Pakistan and promoted religious education in the country. Hundreds of madrassas were established in the early 1980s and this was the period when Afghan jihad enlarged. So far, the total number of the registered madrassas has increased to approximately 40,000 since 1979. According to Murphy, there were 900 madrassas in Pakistan in 1971 but by the end of Zia era in 1988, there were 8000 registered and over 25,000 unregistered madrassas in the country. The unofficial estimates of number of madrassas are more than the official records. Strength of Deobandi's madrassas rapidly increased during this period because the state favoured the Deobandis over the Barelvis. One of the most negative effects of Zia's initiatives was his attempt to Islamize Pakistani society according to his own narrow interpretation of puritanical Sunni Deobandi Islam (Murphy, 2013, p. 87-91). It is a fact that majority of Muslims in Pakistan follows the Sunni-Barelvi School of thought (Rana, 2015). People of another Sunni group "Ahle Hadith," the closest sect to Saudi regime were, also permitted in Pakistan. Regarding students of madrassas in Pakistan, one report claims that some 3.5 million students were enrolled with 35,337 madrassas in Pakistan.

On the other hand, Sunni-Shia divisions also assumed during Zia's era. The Pakistani Shia community was inspired by Iran's revolution and Shia groups and madrassas also increased during this period. Pakistan became not only a base for Afghan Jihad but also a battlefield for Arab-Iran disputes through their proxies in the country. Reactionary agitation of the Shia groups to Zia's biased Islamization in Pakistan also resulted in the additional introduction of Sharia laws favoring the Shia sect in the legal modifications. Zia's policies, especially Islamization, created a great impact on various aspects of the society such as the individuals and institutions of the civil service, armed forces and the educational system. The religious thoughts became to dominate over the public disco- 
urse where many religious offshoots had coexisted for a long time. It encouraged religious and sectarian identity of the people of Pakistan.

Zia's education policy also introduced mosque schools (religious schools in Mosque) and transformed the madrasas "into an integral part of the national educational system." Then government under its policy directed the University Grants Commission (Higher Education Commission now) to take necessary steps for equivalence of madrassas' degrees and certificates with the regular universities and schools' qualifications. The process was completed without changing curriculum and balancing of the standards of studies of both parallel educational systems. It was the Zia era, when Saudi Arabia started to support jihadi madrassas and religious jihadi culture in the society of Pakistan. Due to religious ideological cohesion, the Saudi, other Arab governments and nongovernmental organizations have given extensive assistance to Salafis/Wahhabis madrasas. The madrassas played key role in jihad and promoted the jihadism in the region. It was the time when Afghan Jihad and then Kashmir were at a peak and the jihadi culture emerged in the Pakistan. While the jihad sentiments were not limited to religious school or madrassa, the regular educational institutions including universities also became witness of discussion about the Afghanistan, Kashmir and Palestinian jihad. Though, at that time, the message of jihad was basically a motivation of jihadis against the communist invaders of Afghanistan, it also effected Pakistan because the vast majority of Pakistanis being Muslims were very sensitive to issues such as jihad. International patrons started to supply arms, literature and funds for the jihadi groups, which definitely created a negative impact on the Pakistani culture.

Pakistan was not so much a witness of sectarian clashes and conflict until the 1980s. Even verbal and written attacks on other religions and sects were also rare. But the arrival of jihadi literature in the society, especially in the curriculum of many of the madrassa in Pakistan, as well as mosques played a key role in spreading jihadi culture in the society.

It was a period, when the jihadi publication was important and many of the madrassas and militant groups attracted a large number of readership in Pakistan. Graffiti, wall-posters and pamphlets carried by the different groups circulated. During that time, some of the groups had slogans, such as "Large Family, Good for Jihad."

\section{RELIGIOUS MILITANCY AND CIVILIAN GOVERNMENTS IN POST ZIA ERAS}

The military ruler General Zia died in a plane crash in 1988 and soon after the incident general parliamentary elections took place in the country and the power was handed over to the newly elected civilian government under premiership of Ms Benazir Bhutto, the leader of the Pakistan Peoples Party. Her government was toppled in 1990 and another political figure, namely $\mathrm{Mr}$ Nawaz Sharif, the leader of Pakistan Muslim League. Nawaz, came in power 
through an electoral process during the same year but this government was also terminated before its legal tenure. Both of the popular political leaders enjoyed twice the power of civilian authority over the country next ten years to Zia's era until the second government of Nawaz Sharif was dismissed by Army Chief General Pervez Musharraf on $12^{\text {th }}$ October in 1999. Though during this mentioned decade, the governments were civilian in power, the military, the most powerful entity of the country, had covert intervention and control over foreign and defence policies of the state, particularly policies on Kashmir and the nuclear program, Afghanistan and some other important and strategic matters. The military preferably also promoted jihad in Kashmir, Afghanistan which caused strengthening of militancy and extremism in the country.

Though Benazir Bhutto's first tenure ended in 18 months, she tried to register madrassa system and investigate the foreign students of these religious schools. Her government was twice removed from power on military direction in 1990 and 1996. The Oxford graduate, Ms Benazir Bhutto's twice successor, Mr Nawaz Sharif, the leader of Pakistan Muslim League (PML) Nawaz group, was a much different personality because he had a better understanding with the military establishment. Nawaz Sharif, the law graduate from Punjab University of Pakistan, established his alliance with the military during Zia's regime when he became Finance and then Chief Minister of Punjab, the most populated province of Pakistan. He also tried to make necessary reforms in madrassa's system but could not complete the job as his second government was dismissed in a military coup. Despite the difficulties in their functioning, the civilian governments did try to contain the power of the religious clergy and to make reforms in religious education but they failed because of lack of support of the military and as well as complicated madrassa's schooling system.

On the other hand, multiplying in the number of madrassas continued in the country in the 1990s. Many more religious schools and mosques were opened which produced thousands of graduates of religious studies. It was the time of end of Afghan jihad and return of Pakistani jihadis in their home country. Foreign non-Afghan fighters also travelled to Pakistan in order to seek another front. Pakistani extremist groups became more active inside the country, many of them supported Kashmir Jihad and many of them promoted the newly emerged militant group "Afghan Taliban." The Afghan Taliban, supported by Pakistani establishment, took over most of Afghanistan. The Taliban's achievements in Afghanistan resulted in further expansion of religious extremism and ambitions of the extremist elements of turning Pakistan into a Sunni state.

\section{RELIGIOUS EDUCATION AND EXTREMISM IN POST 9/11 ERA IN PAKISTAN}

The situation totally changed in the post 9/11 era of 2001. It was the pre 9/11 period that many of the madrassas in Pakistan were used by Pakistani 
and Afghani groups with American and Arab money as recruiting and training centers for Afghan jihad. In the post 9/11 episode, for the first time, the madrassa was apparently declared as a source of militancy and terrorism in the region. Earlier, it was the madrassas that had encouraged their students to join the Afghan Mujahideen inside Afghanistan. Madrassa of "Haqqania" in Pakistan headed by a Deobandi religious figure, namely Maulana Sami ul Haque, played very active role in motivation of Afghan jihad against the Soviet Union. Two other Pakistani religio-political groups, namely Jamat e Islami and Jamiat Ulmaye Islam (JUI) headed by Maulana Fazl ur Rehman, were also involved in the Jihad of Afghanistan. The religious seminaries attracted not only Pakistani and Afghanis but also volunteers from Arab states, Central Asia, North Africa and Caucasian Muslim regions to participate in the Afghan war. Soon after the Afghan Jihad, the trained jihadi elements of these madrasas remained and spread in the Pakistani society and also looked inwards fighting against sectarian rivals in Pakistan. Factions of Deobandi groups, such as the Sipah-eSahaba, is one of the examples of the sectarian violent Deobandi organization in Pakistan. At the end of Afghan jihad, the Kashmir jihad began and the state's machinery ignored violence while promoting activities of some of the groups and exploiting them for the similar idea of Jihad but against India in Kashmir; they were also used for some domestic politics.

After a decade of Kashmir jihad, Musharraf's regime came into power and banished some of the jihadi groups involved in Kashmir, including Jaish-eMohammed (JM) and Lashkar-e-Tayaba (LeT), as well as many of the sectarian parties, mostly Deobandi and Shia violent groups, including the Sipah-eSahaba Pakistan (SSP), Lashkar-e-Jhangvi, Tehrik Nifaz-e-Shariah Mohammedi (TNSM), and Sipah-e-Mohammed, Tehrik e Jafria.

It was the time when the mainstream Sunni Barelvi groups were absent from militancy and despite that some of the Barelvis received aid from some Arab countries they also had their bitter rivalry with the Deobandi sect in Pakistan. One of the Barelvi groups, namely Sunni Tehrik, was involved in the limited extremist actions as these activities were against Deobandi extremist groups Sipah-e-Sahaba Pakistan (SSP) in issue of controlling some of the mosques and madrassas in Karachi and Hyderabad cities.

The Musharraf government proposed not only restrictions on the extremist groups but also some reformsproposed some reforms for registration and regulation of madrassa's system. The government issued an ordinance which emphasized mandatory registration and official financial scrutiny of the madrassas. Under the new rules, the madrassa's administration was also offered financial assistance, new curriculums and teacher training. Although it was a significant project for making reforms in the madrassa's system, it was not fully implemented due to differences among the government departments and the differences between the government and religious figures of the country. At the same time, Musharraf's regime started to politicize Sufi Islam by empowering Barelvis in order to counter the threat of extremism, especially Deobandi extremism which was designed by the state itself during Afghan Jihad in the 1980s. 


\section{ESCALATION OF BARELVI'S FANATICISM IN PAKISTAN}

Establishing the "National Council for Promotion of Sufism" by the Musharraf's government was one of the examples of state's support of Sufism or Barelvi Islam. The steps taken by the government later on also caused impetus of some of the Barelvi groups to indulge in extremist activities. Though it was argued that Sufism was based on tolerance and harmony which suited Pakistan's diversity, the results of the state's measures were not totally productive. Beside the government of Pakistan, the U.S. also took a great interest in sponsoring some Barelvi's groups, including Sunni Ittehad Council (SIC), for countering the influence of the extremist ideologies. In the post Musharraf period, the Pakistan People's Party's government also continued to promote Sufism in order to counter the threat of extremism and terrorism. The 'Sufi Advisory Council' (SAC) was established by this government. Many of the Barelvi clerics backed the government position for declaring the Deobandi people as responsible of the religious extremism and sectarian violence in the society (Suleman, 2017b).

Although it created harmony in the society, the situation suddenly changed in 2010, when the prominent figure of ruling party (Pakistan People Party) and Governor of Punjab Salman Taseer announced support for a Christian lady jailed on blasphemy charges. The Governor Taseer declared the current blasphemy law of the country as a "Black Law" and also proposed some amendments in this law. Some of the the Barelvi clerics who were considered as followers of a peaceful version of Islam sharply rotated against the verdict of Salman Taseer and declared him a 'blasphemer'. The clerics started to mobilize their supporters against Salman Taseer and called for his execution, accusing him of blasphemy. Even some of the Barelvi religious figures set bounty on Salman Taseer's head. As the result of the drive, a follower of Barelvi sect, Mumtaz Qadri, who was security guard of Salman Taseer, killed him in Islamabad on $4^{\text {th }}$ January 2011. Many of the Barelvi figures and their followers celebrated his murder and demanded the government to release the assassin. The Sunni Ittehad Council (SIC) started a drive to get him free from prison. The movement resulted in the formation of another violent Barelvi group named "Labaik Ya Rasool Allah" (known as Labaik group). The new organization started to influence people through fanatic speeches and rallies throughout the country. In his critical speeches, a leader of group, calling himself Ameer-ul-Mujahdin (the commander of holy warriors), started to openly challenge government and provoked the masses to kill the blasphemers. This was a turning point in which the emerging trend of Barelvi extremism on the blasphemy issue vibrated in Pakistani society, especially the provocative speeches by fanatic clerics which caused many terrible blasphemy related incidents in different areas of the country, including the murder of a student leader of a university in city of Mardan in Khyber Pakhtunkhwa province, a violent procession in Chitral and murder of two sisters and a man booked for blasphemy in Siakkot city of Punjab. The main political manifesto of the Labaik group who has so far registered itself 
with Election Commission of Pakistan as a political party, is to secure the sanctity of the Prophet (PBUH) and the death of anyone who commits blasphemy (Suleman, 2017b).

The group has been supported not only in Pakistan but also by the Pakistanis based in other countries of the world. The religious extremism in Pakistan is not a new trend and many of such religious groups already exist in the country, which is a witness to deficiency of social tolerance and a lot of exploitations of the sensitive religious issues for their specific interests. Mobilizing the masses and challenging the state machinery on the issues are routine matters.

The discussion on sectarian and other forms of religious violence in Pakistan generally excluded the Barelvi sect as their leadership who were historically against any form of religious and sectarian violence but it is now a fact that the extremism and intolerance in Pakistan also affected the Barelvis. In the current prevailing situation it seems that the Barelvis who had liked to live in peaceful environment and had loved folk-Sufi music are alarmingly changing for the worse.

\section{FINDINGS}

The state of Pakistan's response to the challenges such as radicalism and violent extremism, including armed militancy, was a short term and transitory basis which left substantive political and socioeconomic problems in the society (Yousaf, 2015, p. 134). Secondly, irregularity in the current system of religious education is one of the causes of the religious extremism and militancy in the country. Beside this issue, there are also many other reasons behind the extremism. Foremost of the reasons and causes could be the following:

- The study found that strength of madrassas of different school of thought increased rapidly in Pakistan since 1970s.

- Some of the madrassas have been identified as a source of religious extremism as well as terrorism, especially providers of suicide bombers in the country.

- Poverty was also one of the reasons that many of the lowest class people preferred to send their children to the madrassa instead the regular school; as a result, the intellectual approach of a large number of the masses changed.

- The swift evolution of the religious schooling caused a decline in general standards of scholarship in the society.

- There is lack of equal educational system for all of the people of the country, which has created a gap in the masses and unequal standard of life.

- Lack of funds allocation by the government for betterment of the education system is also one of the causes of the problem.

- Pakistan's interference in Afghanistan during Afghan war later caused grave consequences for the country itself. 
- The religious extremism, fanaticism and militancy created severe political, social and economic impact on the Pakistani society.

- Pakistan's military, the country's most powerful entity, supported or ignored the activities of some of the religious extremist groups in the country, which also caused spreading extremism in the country.

- The state exploited some of the groups for pressurizing others and such trends encouraged these groups to conduct the activities for their own interests.

- The religious clerics belonging to Deobandi sect exploited the opportunity during Afghan jihad and increased the number of their madrassas and spread controversial narrative in the county.

- The religious clerics belonging to Barelvi sect also exploited the state's support during Musharraf's regime and later on, instead of countering extremism, they also increased their extremist activities in the county.

- The exploitative role of so called religious scholars, who support extremism and terrorism, is one of the major problems related to extremism in Pakistan.

- Some of the religious schools and religious groups receive funds without proper state control.

- Some of the groups in the country are being used as proxies of other states and non-state actors.

- The weak policies of the governments in different eras since the 1970s encouraged religious and sectarian identity, instead of national identity of Pakistan.

\section{RECOMMENDATIONS}

- If the state really intends to address the challenges of religious extremism and militancy, it should make sincere reforms in the religious education system by creating a permanent authority for monitoring the system.

- Madrassa's system should be modernized and its curriculum should include modern and scientific education and the skillful students of the religious schools should be adjusted in the mainstream through job market of the country.

- All madrassas should be given equal degree awarding status such as the government's regular schools, colleges and universities but side by side, their standard of education should also be like regular educational institutions.

- All the existing systems of private schools and colleges should be brought into line and equal to government system of education through a national education policy.

- The religious scholars and teachers of the religious schools should be taught and equipped with research based religious and conventional 
and modern education as it can bring positive change in the society.

- Teachers of religious schools should be provided proper and regular training facilities by the government and overall state's budget in education sector should be increased.

- Foreign donations for the religious schools should be regulated through the state and a monitoring system should be adopted for scrutiny of the funds.

- Pakistan must stop exploitation of some foreign proxies for a proxy battle on its land.

- All terrorists or criminal groups must be treated as criminals by the government. National narrative from government side must be equal and open to all of the groups.

- State should avoid favouring the extremist groups while discouraging them by strict actions against the extremism.

- Massive development projects should be launched on equal and merit basis all over Pakistan.

\section{CONCLUSION}

There are many factors involved in growth of extremism and militancy in Pakistan. Basically, local and foreign sponsorship of the different religious groups for specific political and strategic objectives caused growth of extremism in Pakistan. In the 1970s, Zia's regime sponsored its favorite religious groups for its autocracy and Afghan jihad and Islamization of the country and madrassa's system played a key role in the context. The state in post Zia rule and post 9/11 era did not give effective response to the extremism while adopting weak policies for countering extremism. Sometimes, the government tried to support Barelvi groups in order to counter the Deobandi groups which resulted in the emergence of extremism amongst these Sufi factions in the country. Madrassa system remained irregular as the governments made some incomplete reforms for registration and regulation of the system. The state could not adopt a proper way of handling the issue of extremism, which enlarged due to Zia's Islamization, Afghan jihad and evolution of irregular religious education since the 1970s. The governments in post 9/11 eras wanted to contain Deobandi extremism through uplifting Barelvis but failed to prevent such developments. Many of the Barelvi's clerics and their followers also used the sensitive matter of the religion as tool and for that they specifically started to exploit issue of blasphemy. It proved that the Barelvis have strong tendencies toward radicalization and extremism on the religious issues such as blasphemy. As a result, the country which has already been facing multiple challenges including different dimensions of religious extremism, now is a witness to another element of the religious fanaticism in the name of the religion. 


\section{REFERENCES}

1. Akram, M. (2017, July 31). The Emerging Brelvi Extremism. Daily Times. Retrieved from https:// dailytimes.com.pk/123139/the-emerging-brelvi-extremism/.

2. Abbas, H. (2005). Pakistan's drift into Extremism: Allah, the Army, and America's War on Terror. New Delhi: Pentagon Press.

3. Butt, S.S. (2006). Deobandi students surpass Barelvis in Pakistan Madrassas: Insightful statistics. Watan Dost. Retrieved from http://watandost.blogspot.com/2006/01/deobandi-students-surpass-barelvis-in.html.

4. Brannon, I. (n.d.). Sufis, Scholars and Scapegoats: Rashid Ahmad Gangohi and the Deobandi Critique of Sufism. Academia. Retrieved December 24, 2017, from https://www.academia. edu/282790/Sufis_Scholars_and_Scapegoats_Rash\%C4\%ABd_A\%E1\%B8\%A5mad_Gangoh\%C4\%AB_D._1905_and_the_Deobandi_Critique_of_Sufism.

5. Dictionary.com (n.d.). Retrieved December 25, 2017, from http://www.dictionary.com/ browse/madrasa?s=t.

6. Fitzgerald, T. (2011). Religion and Politics in International Relations: The Modern Myth. London: Bloomsbury Publishing.

7. Gul, I. (2012). Pakistan Before and After Osama. New Delhi: Roli Book Private Limited.

8. Haqqani, H. (2005). Pakistan between Mosque and Military. Washington: Carnegie Endowment for International Peace.

9. Javaid, U. (2013). Pakistan Fights Extremism and Terrorism. Lahore: Vanguard Books.

10. Khan, R.M. (2011). Afghanistan and Pakistan: Conflict, Extremism, and resistance to Modernity. Washington: Woodrow Wilson Center Press.

11. Lewis,M.W. (2010). Deobandi Islamvs. Barelvi IslaminSouth Asia. GeoCurrents. Retrieved from http://www.geocurrents.info/cultural-geography/deobandi-islam-vs-barelvi-islam-insouth-asia\#ixzz54AFZHrrm.

12. Murphy, E. (2013). The Making of Terrorism in Pakistan, Historical and Social Roots of Extremism. New York: Routledge Publisher.

13. Rana, M.A. (2015). The Militant. Islamabad: Narratives.

14. Rahman, T. (2016). The Madrassa and the State of Pakistan. Himal South Asian. Retrieved from http://m.himalmag.com/the-madrassa-and-the-state-of-pakistan-tariq-rahman/.

15. Report Says over 35,000 madrassas operating in Pakistan (2015, July 31). Pakistan's Today. Retrieved from https://www.pakistantoday.com.pk/2015/07/31/report-says-over-35000madrassas-operating-in-pakistan/.

16. Suleman, M. (2017a). Contemporary wave of Barelvi extremism. Daily Times. Retrieved from https:/ / dailytimes.com.pk/115150/contemporary-wave-of-barelvi-extremism/

17. Suleman M. (2017b). The Rise of Barelvi Extremism in Pakistan. IAPS DIALOGUE. Retrieved from https:/ /iapsdialogue.org/2017/09/21/the-rise-of-barelvi-extremism-in-pakistan/

18. Sajjad, F. ( 2015). Countering Extremists' Narrative in Pakistan. NDU Journal, 24 (4), 76-79. Retrieved from http://www.ndu.edu.pk/issra/issra_pub/articles/ndu-journal/NDUJournal-2015/04-Countering-Extremists-Narratives.pdf.

19. Simpson, J, \& Weiner, E. (1989). The Oxford English Dictionary (OED). Oxford: Oxford University Press. Retrieved from https://en.oxforddictionaries.com/definition/madrasa.

20. Schubel, V. (2017). Religious Extremism: Not an Excess of Religion, But A Lack of Humanity. Huff Post. Retrieved https://www.huffingtonpost.com/entry/religiousextremism-not-an-excess-of-religion-but_us_589faaf2e4b0e172783a9d37.

21. Said, M.S., \& Ahmad, T. (2016). Institutionalization of Sufi Islam After 9/11 and Rise of Barelvi Extremism in Pakistan. Journal of Society, Education and Language PJSEL 2 (1), 4-5.

22. Yousaf, M.W. (2015). Insurgency and Counterinsurgency in South Asia. New Delhi: Thomson Press Limited.

23. Zaidi, M. (2012). Insights on Insecurity in Pakistan. Islamabad: Narratives Private Ltd. 